\title{
Effect of Saponins Mitigation of Methane - A Review
}

\author{
Anant Simran Singh and Prabhjot Kaur* \\ College of Veterinary Sciences, Near Gaushala, Rampura phul, India \\ *Corresponding author
}

A B S T R A C T

\begin{tabular}{l} 
Ke y w o r d s \\
Herbal feed \\
additives, \\
$\begin{array}{l}\text { Greenhouse gasses, } \\
\text { Saponins, Total } \\
\text { mixed ration, } \\
\text { Methanogenesis }\end{array}$ \\
Article Info \\
$\begin{array}{l}\text { Accepted: } \\
\text { 26 May } 2020 \\
\text { Available Online: } \\
\text { 10 June } 2020\end{array}$ \\
\hline
\end{tabular}

With technological advances made during $21^{\text {st }}$ century we are facing a global threat in form of global warming which is leading to raised average earth temperature and melting of the ice caps from Polar Regions of Earth. Methane has much more GHG effect as compared to carbon dioxide. Ruminant livestock forms a major component among anthropogenic methane leading to increased GHG effect. To overcome this situation, the most promising way to mitigate enteric methane production is either through dietary manipulation by supplementing TMR with herbal feed additives containing saponins as an active principal. Saponins are amphipathic glycosides which can produce soap like foam when shaken in aqueous solution and thus can show positive or negative effects upon microbial activity to impact fermentation, protein degradation and methane production depending upon amount of doze given. There is a need for identifying feed additives with the potential to modify rumen fermentation for enhancing the efficiency of utilization of feed energy while decreasing rumen methanogenesis. However amount of saponins to be provided so as to increase nutrient digestibility needs further investigation as there is very fine line between positive and negative effects of saponins.

\section{Introduction}

Methane forms major part of greenhouse gases and in recent year's greenhouse gases has become major concern as global warming is a ticking time bomb for our planet. Methane is a by-product of anaerobic fermentation and leads to approximately 2$12 \%$ of GE losses. Takahashi, 2011 estimated that livestock are the reason for approximately $15 \%$ of the total atmospheric methane. A decrease in methane production will not only help in reduction of environmental stress but will also improve feed utilization efficiency of the animals (Yurtseven and Ozterk, 2009; Yurtseven et al., 2009). A wide research has been carried on upon large number of techniques involving defaunation, manipulation of ruminal microflora using antibiotics, changing ruminal microflora genetically however nutritional techniques by feeding of herbal feed additives have shown most promising results (Bakshi and Wadhwa, 2009; Wadhwa and Bakshi, 2009 and Bakshi and Wadhwa, 2011). A numerous research on potential of plant secondary metabolites to manipulate ruminal micro flora has been conducted (Wallace et 
al., 2002). A large number of plant bioactive compounds have been identified which could which are composed of steroids, triterpinoids and steroid alkaloids (Wina et al., 2005). Plants secondary metabolites (PSM), such as saponins, tannins, flavonoids, organosulphur compounds, and essential oils, have antimicrobial activities against several types of microorganisms (Patra 2012). There are various researches showing saponins having potential to modulate ruminal fermentation and increasing feed utilization efficiency in ruminants (Patra and Saxena, 2010, Wallace et al., 1994, Hirstov et al., 1999). In vitro studies carried by (Hu et al., 2005, Lila et al., 2003) and in vivo studies carried by (Yuan et al., 2007) has shown promising reduction of ruminal ammonical-N and $\mathrm{pH}$. However Lovett et al., 2006 reported decreased, Holtshausen et al., 2009 increased and Mao et al., 2010 reported no effect upon feed intake on supplementation of saponins.

\section{Methane production among ruminants}

Farmed ruminants form a very large portion of total anthropogenic methane emissions globally. Methanogens present in ruminal flora primarily uses Hydrogen $[\mathrm{H}]$ produced during anaerobic carbohydrate fermentation. Ruminal microflora can convert plant fiber unavailable for humans into microbial protein available for absorption for ruminants with biological value 70 . Methane (CH4) acts as main sink for metabolic Hydrogen $[(\mathrm{H})]$ produced during ruminal fermentation. Metabolism of carbohydrates by the fermentative microbiota of bacteria, protozoa and fungi reduces co-factors, which are reoxidized mostly by transferring electrons to protons. Dihydrogen $(\mathrm{H} 2)$ so formed is transferred to methanogenic Archaea, which utilize it to reduce carbon dioxide (CO2) to CH4 (Russel et al., 1997). Energy lost as CH4 is an inefficiency in the conversion of digestible energy (DE) to metabolizable energy (ME), because $\mathrm{CH} 4$ is formed from organic matter (OM) digested and fermented in the rumen and hindgut (Hill et al., 2016).

\section{Saponins}

Saponins are naturally occurring surfaceactive glycosides, found in various plants in different forms and structures (Vincken et al., 2007). A great many of studies have been conducted to investigate the effects of different saponins on rumen microbial fermentation characteristics and methanogenesis (Lila et al., 2003; Wina et al., 2005; Guo et al., 2008; Pen et al., 2008; Patra and Saxena 2009b and SzumAcherStrabel and Cieslak, 2010). However, the results varied depending on the types, doses and structures of saponins, because saponins have different biological activities 4 according to their aglycone portion and combined sugar body of the structure (Hassan et al., 2010). The primary effect of saponins in the rumen appears to be to inhibit the protozoa (defaunation), which might increase the efficiency of microbial protein synthesis and protein flow to the duodenum. Furthermore, saponins may decrease methane production via defaunation and/or directly by decreasing the activities (i.e. rate of methanogenesis or expression of methane-producing genes) and numbers of methanogens. Saponins may also selectively affect specific rumen bacteria and fungi, which may alter the rumen metabolism beneficially or adversely. It was reported that saponins had the potential to suppress methanogenesis, reduce rumen protozoa and modify rumen fermentation. Sirohi et al., (2014) concluded that saponin fraction of Albizia lebbeck has antimethanogenic potential and has an ability to modulate the rumen fermentation parameters.

\section{Effects of saponins on DMI and digestibility}

The effects of saponins on feed intake and digestibility are variable. By addition of 
saponins in the diets of ruminants, feed intake decreased (Wu et al., 1994, Lovett et al., 2006), increased (Holtshausen et al., 2009, Abreu et al., 2004 and Aregheore, 2005), or remained unaffected (Klita et al., 1996, Hess et al., 2004, Singer et al., 2008, Mao et al., 2010). As far as digestibility is concerned, was not affected by saponin supplementation. Sliwinski et al., (2002) and Lila et al., (2005) showed that the apparent digestibility of the nutrients was not affected by saponin supplementation. However, some studies found that the apparent digestibility of OM, $\mathrm{CP}$, and NDF decreased with the addition of saponin in the diets (Klita et al., 1996 and Hess et al., 2004). This was probably due to an increased flow of material to the duodenum by supplementing with saponin (Klita et al., 1996).

Anantasook et al., (2013) observed no negative effect was observed on feed intake when rain tree pod meal (RPM) and/ or palm oil (PO) was added to the diet of dairy cows. Furthermore, fiber digestibility and cellulolytic bacteria were increased withh supplementation with PO. Supplementation of RPM lowered CP digestibility, $\mathrm{NH}_{3}-\mathrm{N}$ concentration, proteolytic bacteria and protozoa populations which resulted in greater microbial crude protein. In addition, efficiency of microbial $\mathrm{N}$ supply was increased in both RPM and RPO treatments. Elmnan et al., (2013) indicated that there was increase in DMI and CPI among groups offered diet supplemented with varying levels of fenugreek seeds than that one offered control diet. These results agree with those reported by Petit et al., (1993) and Abo ElNor (1999) who found that (DM) Intake was increased when lactating buffaloes fed different levels of fenugreek seeds. Tomar et al., (1996) found that the fenugreek seed stimulates feed intake in dairy cattle, resulting in a significant increase in milk production. Ismail (2000) who fed growing Barki lambs fenugreek seeds and found that DM intake increased gradually as the level of fenugreek seed increased. The increased of DMI and CPI among groups fed diet supplemented with varying levels of fenugreek seeds than that one fed control diet, firstly may be due to the saponins content in fenugreek seeds, which increased feed intake. The boosting effect of fenugreek seeds supplementation might also be attributed to the fact that fenugreek seeds increase the appetite for food (Borca et al., 2000). They showed that there was increased in nutrients digestibility of (DM, CP and OM) in supplemented groups than control. This results agree with (Abo ElNor et al., 2007) who found that there was an improvement in digestibility co-efficient of lactating buffaloes fed different levels of fenugreek seeds. The improvement in digestibility could be justified on the basis of that fenugreek seeds contain saponins which stimulate anaerobic fermentation of organic matter that improve efficiency of utilization of nutrients (Abo El-Nor et al., 2007). In addition fenugreek seeds increased bacterial number in the rumen of lactating cows (Valdez et al., 1986, AlAli et al., 2005). The results revealed that NDF digestibility decreased in treated diet compared to control diets may be explained by $\mathrm{Lu}$ and Jorgensen (1987) who observed that saponins impaired fiber digestion in the rumen. Moreover, saponins may decrease cellulolytic bacteria rather than amylolytic bacteria (Wang et al., 1998, Wang et al., 2000).

Consistent with our findings, some earlier workers also did not find any effect of saponin supplementation on DMI (Nasri et al., 2011). However, others reported improved DMI with saponin supplementation (Hu et al., 2006). Kumar et al., (2017), observed no such effect observed on feeding either tea seed or TSS (during short term or long term) on DMI to Gaddi goats. Saponins are bitter in taste, highly soluble in water and 
at higher dose level may depress intake due to low palatability ( $\mathrm{Li}$ and Powers 2015). It was reported, 5\% increase in DMI when TSS was fed at the dose of $0.25 \%$ and $27 \%$ decrease in DMI when fed at $0.5 \%$ (Li and Powers 2015). However, we did not observe any negative effect on intake at the dose level studied.

There was no significant difference in digestibility of DM, OM, CP, NDF, and ADF during both short term as well as long term in Gaddi goats. However, during short term the EE digestibility was low $(\mathrm{p}<0.05)$ in $\mathrm{T}_{1}(54.58 \%)$ and $\mathrm{T}_{2}(54.68 \%)$ groups as compared to control $(58.83 \%)$. Whether saponin had any role in reduction in $\mathrm{EE}$ digestibility during initial period is not clear. Similar to findings of Kumar et al., (2017) no effect on digestibility due to feeding saponin containing diet in ruminants was reported by many workers (Nasri et al., 2011).

The administration of 30,60 , or $90 \mathrm{mg}$ of Quillaja saponarie per kg DMI had no effects on feed digestibility in Barbarine lambs and in another study (Aazami et al., 2013) administration of 100 or $200 \mathrm{mg} / \mathrm{kg}$ DMI of Quillaza saponin also did not affect digestibility in Baluchi sheep. Contrary to our findings, supplementation of high doses of saponin decreased the digestibility of nutrients and linear decrease in apparent digestibilities of DM, OM, CP, and NDF with supplementation of saponin from Biophytum petersianum in goats, lucerne and Sapindus saponins in sheep were observed (Santoso et al., 2007). In contrast, positive effect of saponins on digestibility was reported in cattle supplemented with sarsaponin (Goetsch and Owens 1985) and in sheep with Sapindus rarak saponin (Thalib et al., 1996). So in some studies where there is substantial decrease in protozoal population and also where there is no compensatory increase in bacterial population there is reduction in digestibility.

\section{Effects of saponins on rumen fermentation}

The effects of saponins on total ruminal VFA production and molar proportions are variable. Agarwal et al., (2006) reported reduced acetate and increased propionate levels with addition of water, ethanol and methanol extracts of soapnut to buffalo rumen liquor, resulting in lower acetate: propionate ratio. TVFA concentration was significantly decreased when extracts (water, ethanol and methanol) of $A$. indica were added in vitro. There was also a decrease in acetate to propionate ratio with addition of $A$. indica and A. concinna (Patra et al., 2006). Lila et al., (2003) reported an increased $(\mathrm{P}<0.05)$ concentration of propionate and butyrate and decreased $(\mathrm{P}<0.05)$ acetate and acetate: propionate ratio. A decrease in molar proportion of acetate and an increase in butyrate were consistent with the results of the in vivo studies by Christopher and Neal (1987). Lila et al., (2003) reported that saponin has a variable effect on ruminal propionate concentration. Other report indicated that propionate production was significantly increased (Grobner et al., 1982), decreased (Hussain and Cheeke, 1995) or remained unaffected (Valdez et al., 1986) on saponin supplementation. The variable effect of saponins supplementation may be due to its type, dose of saponin and composition of diet. The ruminal ammonia production is reduced with saponin supplementation. Grobner et al., (1982) found a $15 \%$ reduction in ammonia concentration when saponins were included at $60 \mathrm{mg} / \mathrm{kg}$ in the incubation medium. The inclusion of yucca saponins in diet of sheep (Santoso et al., 2004) or in vitro ruminal culture fermentation (Wallace et al., 1994 and Wang et al., 2000), the ruminal ammonia concentration was reduced significantly. Hristov et al., (1999) also reported the decreased $(\mathrm{P}<0.05)$ ruminal ammonia concentration $2 \mathrm{~h}$ after YS dosing (at 20 or 60 $\mathrm{g} / \mathrm{d})$ relative to control but the acidity, 
concentrations of reducing sugars, free amino acids, and peptides in the rumen remained unaffected $(\mathrm{P}>0.05)$.

Szczechowiak et al., (2013) used Saponaria officinalis (SO) or Panax ginseng (PG) saponins @1\% on dry matter basis with high and low forage diets containing meadow hay and corn meal in 60:40 and 40:60, respectively and observed a significant decrease $(\mathrm{P} \leq 0.05)$ in $\mathrm{pH}$ was observed in case of experimental group as compared to control for both HF and LF diet.A significant increase in acetate and propionate contents were observed for treatment in comparison to control leading to decreased A:P by $18 \%$ for SO and $51 \%$ for $\mathrm{PG}$ saponins in $\mathrm{HF}$ diets. Addition of $\mathrm{PG}$ increased $(\mathrm{P} \leq 0.05)$ butyrate, iso-butyrate and iso valerate concentrations. However in LF diet Supplementation with PG also increased the molar concentrations of propionate, butyrate, iso-butyrate and isovalerate. VFA profile of rumen fluid incubated with PG lowered the acetate and valerate contents and the acetate to propionate ratio, by $22 \%, 57 \%$ and $45 \%$ respectively, when compared to the controls Though there was no effect on $\mathrm{CH}_{4}$ production in $\mathrm{HF}$ diet yet dietary supplementation of $\mathrm{PG}$ and $\mathrm{SO}$ resulted in $8 \%$ lower $\mathrm{CH}_{4}$ concentrations than in the control group in case of LF diet. Istiqomah (2011) studied the effect of waru leaf (Hibiscus tiliaceus) supplementation as saponin@5,10,15, and 20\% saponin level added to feed substrate of Napier grass (Pennisetum purpureum). There was direct relationship in decrease in protozoal number and total gas production $(\mathrm{P}<0.05)$ with increase of saponin source, however there was no effect on $\mathrm{NH}_{3}$, VFA concentration and $\mathrm{pH}$ after $48 \mathrm{~h}$ fermentation were not affected by the treatment. VFA concentration increased by waru leaf up to $10 \%$ saponin level then decreased at level 15 and 20\%. Although ratio of acetate to propionate (A/P) and non glucogenic ratio (NGR) decreased at 5, 10, and $15 \%$ saponin level, but increased at level $20 \%$. It could be concluded that waru leaf supplementation at $10 \%$ saponin level of feed was the optimum level which gave positive effect on rumen feed fermentation.

A study was conducted by Manatbay et al., (2014) to investigate the effects of gynosaponin on in vitro methanogenesis and fermentative efficiency under different forage-concentrate ratios ( $\mathrm{F}: \mathrm{C}$ ratios). A $70: 30$ and 30:70 ratios of forage and concentrate were used with two levels of gynosaponins 0 and $16 \mathrm{mg}$. A decrease in acetate with increased propionate leading to decreased A:P $\quad(p<0.05)$ was observed on addition of gynosaponins in case of high forage diets. However an increase in butyrate $(\mathrm{p}<0.05)$ was observed in both the $\mathrm{F}: \mathrm{C}$ ratios. Jayanegra (2014) analyzed 23 studies about saponin containing PSM and observed a curvilinear pattern between methane production and saponin supplementation. He observed, saponins added above $500 \mathrm{mg} / \mathrm{g}$ DM were effective in reducing methane production. On expression of $\mathrm{CH}_{4}$ as $\mathrm{ml}$ per $100 \mathrm{~mL}$ total gas produced, a linear decrease in $\mathrm{CH}_{4}(\mathrm{p}<0.01)$ was observed with increasing levels of the saponin-rich source. A decrease in total gas production (curvilinear; $\mathrm{p}<0.05$ ), OMD $\quad(\mathrm{p}<0.01) \quad$ and rumenal $\mathrm{NH}_{3}$ concentration $(\mathrm{p}<0.1)$ were observed on increasing saponin levels. Whereas SCFA production, the respective parameter increased linearly $(p<0.01)$ with increasing levels of saponin-rich source. A decrease in proportion of acetate (linear pattern; $\mathrm{p}<0.05$ ) and increase in propionate (linear pattern; $\mathrm{p}<0.01)$ was observed which further led to decreased A:P. Log protozoal count decreased significantly $(\mathrm{p}<0.05)$ at higher saponin levels.

Belanche et al., (2016) evaluated ivy fruit saponins (IVY) as a natural feed supplements and observed that it had no nutritional value, 
rather it had antimicrobial effects leading to decreased methane production due to decreased methanogens. Kang et al., (2016) investigated the effects of Momordica charantia saponin (MCS) on ruminal fermentation of maize stover and abundance of selected microbial populations in vitro. Five levels of MCS supplements (0, 0.01, $0.06,0.30,0.60 \mathrm{mg} / \mathrm{mL})$. The high dose of MCS increased the initial fractional rate of degradation at $\mathrm{t}$-value $=0\left(\mathrm{FRD}_{0}\right)$ and the fractional rate of gas production $(k)$, but decreased the theoretical maximum of gas production $\left(V_{\mathrm{F}}\right)$ and the half-life $\left(\mathrm{t}_{0.5}\right)$ compared with the control. The $\mathrm{NH}_{3}-\mathrm{N}$ concentration reached the lowest concentration with $0.01 \mathrm{mg} \mathrm{MCS} / \mathrm{mL}$ at $6 \mathrm{~h}$. The MSC inclusion increased $(\mathrm{p}<0.01)$ the molar proportion of butyrate, isovalerate at 24 $\mathrm{h}$ and $48 \mathrm{~h}$, and the molar proportion of acetate at $24 \mathrm{~h}$, but then decreased $(\mathrm{p}<0.05)$ at $48 \mathrm{~h}$. The molar proportion of valerate was increased $(\mathrm{p}<0.05)$ at $24 \mathrm{~h}$. The acetate to propionate ratio (A/P; linear, $\mathrm{p}<0.01)$ was increased at $24 \mathrm{~h}$, but reached the least value at the level of $0.30 \mathrm{mg} / \mathrm{mL}$ MCS. The MCS inclusion decreased $(\mathrm{p}<0.05)$ the molar proportion of propionate at $24 \mathrm{~h}$ and then increased it at $48 \mathrm{~h}$. The concentration of total volatile fatty acid was decreased $(p<0.01)$ at $24 \mathrm{~h}$, but reached the greatest concentration at the level of $0.01 \mathrm{mg} / \mathrm{mL}$ and the least concentration at the level of $0.60 \mathrm{mg} / \mathrm{mL}$.

Galindo et al., (2016) used raw saponin extract of Sapindus saponaria on basal diet of star grass (Cynodon nlemfuensis) @ $0.6 \%$, $1.2 \%$ and $1.8 \%$ of the DM basis and observed no change in acetic acid on addition of saponins, however the propionic acid reduced at $1.2 \%$ inclusion level. A gradual decrease in valeric acid was observed with gradual increase in saponin level as 0.68 ; $0.62 ; 0.52$ and 0.49 mmol. $\mathrm{L}^{-1}$ for $0,0.6,1.2$ and $1.8 \%$ of saponin extract, respectively.

\section{Effects of saponins on microbial population}

The effect of saponins on rumen bacteria is contradictory. Growth of cellulolytic bacteria has been decreased (Ningrat et al., 2002), increased (Thalib et al., 1995) or unaffected (Wina et al., 2005) by the presence of $S$. rarak saponins. Goel et al., (2008a) used saponin fraction from sesbania, cardus and knautia leaves and fenugreek seeds and found decreased protozoa (10-39\%), fungal (20$60 \%)$, Fibrobacter succinogenes (21-45\%) and Ruminococcus flavefaciens $(23-40 \%)$ population. The relative abundance of Ruminococcus was little affected by tea saponins (TS), but Wang et al., (2000) reported that the growth of Ruminococcus was negatively affected by saponins from Yucca. Saponins from Sesbania pachycarpa enhanced the growth of Ruminococcus (Muetzel et al., 2003). The differences among these results may be due to the different types of saponins used. The supplementation of saponins, or saponin-rich feeds such as Yucca schidigera and Quillaja saponaria, also decreased ciliate protozoa population in vitro (Makkar et al., 1998, Pen et al., 2006) as well as in vivo (Valdez et al., 1986). Protozoa were sensitive to saponins because their membrane sterols bind with saponins (Wina et al., 2005). But contrary to these findings, Sliwinski et al., (2002) did not observe any effect on protozoal numbers by saponin-rich products containing sarsaponin. In long term trial with sheep at the level of $0.24,0.48,0.72 \mathrm{~g}$ Sapindus rarak saponins $/ \mathrm{kg}$ body weight, protozoa numbers were decreased but not in short term trial of 7 days. Feeding of $60 \mathrm{~g}$ of $Y$. schidigera extract containing $10 \%$ saponins to dairy cattle had no antiprotozoal effect (Benchaar et al., 2008). The inconsistencies of the effects of saponins on protozoa in some studies might be due to different doses of saponins used. Rain tree pod meal, which contains condensed tannins and saponins, has the potential to manipulate rumen 
fermentation by depressing protozoa and methanogens thereby reducing methane production in in vitro (Anantasook and Wanapat, 2012).

Szczechowiak et al., (2013) used RUSITEC to study the effect of Saponaria officinalis (SO) or Panax ginseng (PG) saponins supplemented high and low forage diets containing meadow hay and corn meal in 60:40 and 40:60, respectively. About 1\% saponin was provided by SO and PG on dry matter basis so as to see their effect upon for rumen microbial fermentation and methane production. They observed a significant decrease $(\mathrm{P} \leq 0.05)$ in number of protozoa by $50 \%$ and $72 \%$ without any effect on methane production was observed for both of the saponin sources in case of HF diet. However in case of LF diet both of saponin sources showed potential to decrease methane by $8 \%$, however decrease in protozoal count was observed only in case of PG.

Manatbay et al., (2014) observed by RT-PCR that $F: C$ ratios significantly affected the abundances of Fibrobacter succinogenes, Rumninococcus flavefaciens, total fungi and counts of protozoa $(\mathrm{p}<0.05)$, but no change was observed in mcr-A gene revealing that number of methanogens showed no significant change. It was also analyzed that there was a significant decrease in abundance of $F$. succinogeneswhereas no significant change was observed for mcrA gene in case of high forage diets when treated with gynosaponins thus gynosaponin treatment under high-concentrate level did not affect the methanogenesis, fermentation characteristics and tested microbes.

Kang et al., (2016) investigated the effects of Momordica charantia saponin (MCS) on ruminal fermentation of maize stover and abundance of selected microbial populations in vitro. Five levels of MCS supplements $\quad(0, \quad 0.01, \quad 0.06, \quad 0.30, \quad 0.60$ $\mathrm{mg} / \mathrm{mL}$ ) and revealed that the relative abundance of Ruminococcus albus was increased at $6 \mathrm{~h}$ and $24 \mathrm{~h}$, and the relative abundance of Fibrobacter succinogenes was the lowest $(\mathrm{p}<0.05)$ at $0.60 \mathrm{mg} / \mathrm{mL}$ at $6 \mathrm{~h}$ and $24 \mathrm{~h}$. The relative abundance of Butyrivibrio fibrisolvens and fungus reached the greatest value $(\mathrm{p}<0.05)$ at low doses of MCS inclusion and the least value $(\mathrm{p}<0.05)$ at $0.60 \mathrm{mg} / \mathrm{mL}$ at $24 \mathrm{~h}$.

\section{Effects of saponins on methanogenesis}

Plant material from Y.schidigera, which is rich in steroidal saponins, and Quillaja saponaria (triterpenoid type saponins) shown enhancement of $\mathrm{N}$ utilization, reduce methane production (Goel and Makkar, 2012). Rodriguez and Fondevila (2012) studied the effect of supplementation of saponin from Enterobacterium cyclocarpum on digestibility of Pennisetum purpureum and observed the reduction in methane production in vitro. Abatement of up to $50 \%$ in methane production with addition of saponin has been reported (Jouaney and Morgavi, 2007, Szumacher-Strabel and Cieslak, 2010).

A comparison of the effects on rumen fermentation of three saponin rich tropical fruits supplemented to forage-based diets was completed using a rumen simulation technique (Rusitec) by Hess et al., (2003). The ruminal methanogens live in association with ciliate protozoa in the rumen. Saponins present in alfalfa (3-5\%), Yucca schidigera (4\%), Quillajasaponaria (10\%), Sesbania sesban, Sapindus saponaria (Soap nut) and Sapindus rarak are supposed to have a potential to suppress or eliminate protozoa from rumen and hence reduced methane emission (Hess et al., 2003 and Wallace et al., 2002). Lila et al., (2003, 2005) found that the numbers of protozoa in rumen liquor decreased from steer fed hay plus a 
concentrate supplemented with saponin, and methane emission decreased approximately $12.7 \%$ in vivo, and $15-44 \%$ at $24 \mathrm{~h}$ fermentation in vitro. Agarwal et al., (2006) observed reduced methane production in vitro with water, ethanol and methanol extracts of Soapnut (Sapindus mukorossi) with highest in ethanol extract (96\%). Addition of tea saponin at 2, 4, 6 and $8 \mathrm{mg}$ against $200 \mathrm{mg}$ mixture in vitro decreased methane concentration by 13 , 22, 25 and 26\%, respectively (Wei-Lian et al., 2005). Pen et al., (2006) demonstrated that Yucca schidigera extract (YSE) decreased methane production in in vitro fermentation experiments using the ruminal fluid of Holstein cows whereas Quillaja saponaria extract (QSE) did not.Sliwinski et al., (2002) comparing Yucca schidigera extract to Castanea sativa wood extract (CSE; containing hydrolysable tannins and lignan) in in vitro rumen models showed effects on methane production only at very high levels. Sliwinski et al., (2002) further concluded that the effects on methanogenesis were inconsistent between in vitro and in vivo data. The inconsistency may be due to difference in basal diets, saponins concentration and adaptation period used.

Ivy fruit saponin decreased $\mathrm{CH}_{4}$ production by $40 \%$, modified the structure of the methanogen community, and decreased its diversity (Belanche et al., 2016). Saponins from Saponaria officinalis decreased $\mathrm{CH}_{4}$ and abundance of both methanogens and protozoa in vitro (Cieslak et al., 2014). However, in other in vitro studies, Quillaja saponins at 0.6 $\mathrm{g} / \mathrm{L}$ did not lower $\mathrm{CH}_{4}$ production or methanogen abundance (Patra and Yu 2014), and Yucca and Quillaja saponins at 0.6 to 1.2 $\mathrm{g} / \mathrm{L}$ even increased archaeal abundance (by 0.3-0.4 log), despite a decrease in protozoal abundance by Quillaja saponin (Patra et al., 2012). Tea saponins (30 g/day) also did not lower $\mathrm{CH}_{4}$ emission from steers or abundance of total methanogens but increased the abundance of RCC methanogens and protozoa (Ramírez-Restrepo et al., 2016). Galindo et al., (2016) used raw saponin extract of Sapindus saponaria on basal diet of star grass (Cynodon nlemfuensis) @ $0.6 \%, 1.2 \%$ and $1.8 \%$ of the DM basis and observed reduction in protozoal levels. PCR-RT used to determine microbial population showed no modification in Fibrobacter succinogenes while the values of Ruminococcus albus were $25.92 ; 26.72 ; 25.2$ and $22.35 \mathrm{CT}$ for the levels $0 ; 0.6 ; 1.2$ and $1.8 \%$, respectively. Thus, the effects of saponins on methanogenesis and methanogen abundance are highly variable among studies.

\section{Nitrogen utilization and Effect on microbial protein synthesis}

Microbial protein synthesis in the rumen provides the majority of protein supplied to the small intestine of ruminants, accounting for 50 to $80 \%$ of total absorbable protein (Firkins et al., 2007). According to Anantasook et al., (2013) the excretion of creatinine and allantoin concentrations in urine were not affected in any of the treatments $(p>0.05)$. In contrast, allantoin absorption and microbial crude protein (MCP) were increased by rain tree pod meal (RPM) supplementation. The MCP flow from the rumen as a result of allantoin absorption ranged from 284.6 to $339.3 \mathrm{~g} / \mathrm{d}$, respectively. Moreover, supplementation of RPM or RPO resulted in the greatest microbial protein synthesis in terms of quantity and efficiency. Similarly, Anantasook et al., (2013) reported that efficiency of microbial protein synthesis was increased in dairy steers supplemented with RPM. Chanthakhoun et al., (2011) also found that feeding Phaseolus calcaratus hay resulted in increasing efficiency of microbial protein synthesis in swamp buffalo. This could be due to effect of RPM reducing the protozoal population which contributed significantly to intra-ruminal cycling of 
microbial $\mathrm{N}$ and reducing the EMPS (Jouany 1996). Therefore, reducing protozoa populations could improve dietary $\mathrm{N}$ utilization and increase MPS flow to the intestine (Wang et al., 2012).

In few studies reported in literature, Chinese workers observed that supplementation with tea seed saponin (TSS) improved rumen fermentation, increased microbial $\mathrm{N}$ yield, decreased methane production (Wang et al., 2012) and improved average daily gain (ADG) (Hu et al., 2006). In contrast, supplementation of TSS at higher dose level decreased dry matter intake (DMI), digestibility and ADG ( $\mathrm{Li}$ and Powers 2015, Jadhav 2014). So the effects of TSS supplementation are not uniform and highly variable depending upon the saponin dose level and type of diet (Patra and Saxena 2010).

Increased $\mathrm{N}$ retention during short term in TSS fed group and increased $\mathrm{N}$ retention in both the supplemented groups during long term indicates that TSS in the diet has some role in improved $\mathrm{N}$ retention (Kumar et al., 2017). In tea seed $\left(T_{1}\right)$ fed group though the $N$ retention was numerically higher during short term, however, only during long term the effect was significant indicating that tea seed supplementation needed more time for getting the beneficial effect as compared to TSS supplementation. Though, linear decrease in urinary $\mathrm{N}$ with saponin supplementation was reported earlier (Santoso et al., 2007) however, we did not observe any effect of supplementation on urinary $\mathrm{N}$.

In the study (Kumar et al., 2017), the microbial protein supply was higher $(\mathrm{p}<0.05)$ for $T_{1}$ and $T_{2}$ during both the periods as compared with control. Similar to our findings, improvement in microbial $\mathrm{N}$ supply has been reported by many workers (Santoso et al., 2007). Ciliated protozoa in the rumen plays significant role in intraruminal cycling of microbial $\mathrm{N}$ and negatively affecting the efficiency of microbial protein synthesis, so reduction in protozoal populations invariably found in saponin supplementation could improve dietary $\mathrm{N}$ utilization and increase microbial protein flow to the intestine (Santoso et al., 2007). Increased microbial biomass, ${ }^{15} \mathrm{~N}$ incorporation and efficiency of microbial protein synthesis with the addition of saponins from Quillaja, Yucca, and Acacia auriculiformis fruit also reported in literature (Makkar et al., 1998). Contrary to our findings, in a previous study (Nasri et al., 2011) it was observed that the total excretion of urinary PD (allantoin, uric acid, and xanthine+ hypoxanthine) and microbial $\mathrm{N}$ supply were not affected by supplementation of Quillaja saponaria saponin extract $(0,30$, 60 , and $90 \mathrm{mg} / \mathrm{kg}$ DMI) in Barbarine lambs.

\section{Effects of saponins on growth}

As being potential alternative to antibiotic growth promoters, many researchers tried saponins in the diets of growing animals. Yucca schidigera saponins supplementation resulted in decreased ruminal ammonia concentration, improved daily gain and feed efficiency in animals (Mader and Brumm 1987, Giesy et al., 1992, Hussain and Cheeke 1995, Kawai et al., 2000 and Mirza et al., 2002). Growth of steers has been reported to improve when supplementing sarsaponin, a steroidal saponin extracted from Yucca schidigera (Zinn et al., 1998). Mirza et al., (2002) found highest average daily body weight gain $(267 \mathrm{~g} / \mathrm{h} / \mathrm{d}$ vs $255 \mathrm{~g} / \mathrm{h} / \mathrm{d})$ in saponins fed group whereas Carcass traits between treatments were found to be statistically similar. Hu et al., (2006) evaluate the effects of the TS addition on growth performance of growing Boer goats for 60 days. The animals received the same basal diets, and added TS at levels of $0(\mathrm{C}), 3 \mathrm{~g}$ (T1) and $6 \mathrm{~g}$ (T2) per day. The higher dry 
matter intake (623 vs 537 or $534 \mathrm{~g} /$ day), average daily gain (94 vs 69 or $71 \mathrm{~g} / \mathrm{d}$ ) and feed efficiency (150 vs 127 or $131 \mathrm{~g} / \mathrm{kg}$ ) in $\mathrm{T} 1$ group than the other two indicated that the TS could modify the ruminal fermentation and that proper doses of TS may have potential in improving the animal growth performance, whereas at high doses, it may have adverse effects on animal production.

Both TS and TSS supplementation improved ( $\mathrm{p}<0.05)$ BW gain as compared to control. These results are in agreement with previous reports (Thalib et al., 1996). ADG of goats recorded in this study was comparable to the performance of the breed for the age group. In a previous study (Hu et al., 2006), it was observed that the goats supplemented with $3 \mathrm{~g}$ of tea saponin/d had higher ADG and FCR than those on 0 and $6 \mathrm{~g}$ of tea saponin/d. In sheep, feeding of Sapindus rarak saponin improved growth rate (Thalib et al., 1996), in contrast, no effect on ADG due to saponin supplementation also reported (Sliwinski et al., 2002). Contrary to these findings, decrease in ADG was also reported when saponin dose level was higher ( $\mathrm{Li}$ and Powers, 2015, Jadhav 2014). It was postulated (Patra and Saxena 2010) that effect of saponin varied depending on type of diet, nature of saponin and dose level which may be the reason for the difference in the effects.

In conclusion, saponins were previously considered as anti-nutritional factors due to their astringent properties leading to decreased Crude Protein digestibility. However now they. However amount of saponins to be provided so as to increase nutrient digestibility needs further investigation as there is very fine line between positive and negative effects of saponins. Effects produced in rumen not only depend upon amount of saponins but also upon physiological status of animals leading to variable amount of methane inhibition.
Respiratory chambers being costly equipment making methane estimation difficult. Though saponins available in natural form are easily available yet industrial extracts of saponins are a costly affair to be used as agricultural by product in developing countries like India.

\section{References}

Aazami M H, Tahmasbi A M, Ghaffari M H, Naserian A A, Valizadeh R E Z A and Ghaffari A H. 2013. Effects of Saponins on Rumen Fermentation, Nutrients Digestibility, Performance, and Plasma Metabolites in Sheep and Goat Kids. Annual Review and Research in Biology 4: 596-607

Abreu A, Carulla J E, Lascano C E, Diaz T E, Kreuzer M and Hess H D. 2004. Effects of fruits on ruminal fermentation and duodenal nitrogen flow of sheep fed a tropical grass diet with and without legume. Journal of Animal Science 82(5): 1392-1400.

Abo El-Nor S A H. 1999. Influence of fenugreek seeds as a galactogogue on milk yield, milk composition and different blood biochemical of lactating buffaloes during mid-lactation. Egyptian Journal of Dairy Science 27: 231-38.

Abo El-Nor S A H, KHattab H M, Al-Alamy H A, Salem F A and Abdou M M. 2007. Effect of medicinal plants seeds in rations on the productive performance of lactating buffaloes. International Journal of Dairy Science 2: 348-55.

AlAli M F, Saleh M S, Eweedah N M and Mohmoud S A. 2005. Effect of using chamomile (Mtricaria chamomilla) flowers as feed additives on performance of growing lambs under desert farming systems. Egypt Journal Nutrition and Feeds 8: $127-37$.

Anantasook N and Wanapat M. 2012. Influence of rain tree pod meal supplementation on rice straw based diets using in vitro gas fermentation technique. Asian Australasian journal of Animal Sciences 25(3): 325-34.

Anantasook N, Wanapat M, Cherdthong A and Gunun P. 2013. Effect of plants containing secondary compounds with palm oil on 
feed intake, digestibility, microbial protein synthesis and microbial population in dairy cows. Asian Australasian Journal of Animal Sciences (AJAS) 26(6): 820-26

Aregheore E M. 2005. Effect of Yucca schidigera saponin on the nutritive value of ureaammoniated maize stover and its feeding value when supplemented with forage legume (Calliandra calothyrsus) for goats. Small Ruminant Research 56(1): 95-102.

Bakshi M P S and Wadhwa M. 2009. Dietary manipulation for mitigation of enteric methane emission. In Proc: 6th Asian Buffalo Congress, Lahore, Pakistan.

Bakshi M P S and Wadhwa M. 2011. Phytogenics: Role in enteric methane mitigation and performance of animals. In: Chaturvedi V B, Dutta N, Verma A K, Singh P and Kamra D N (Eds.) Nutrition Inventions for Clean and Green Livestock Production, CAFTAN, IVRI, Izatnagar. pp 180-84.

Belanche A, Pinloche E, Preskett D and Newbold C J. 2016. Effects and mode of action of chitosan and ivy fruit saponins on the microbiome, fermentation and methanogenesis in the rumen simulation technique. FEMS Microbiology Ecology 92(1): 160.

Borca C, Manteghetti M and Corss R. 2000. 4Hydroxyisoleucine: effect of synthetic and natured analogs on insulin secretion. European Journal of Pharmacology 390: $339-54$

Chanthakhoun V, Wanapat M, Wachirapakorn C and Wanapat S. 2011. Effect of legume (Phaseolus calcaratus) hay supplementation on rumen 90 microorganisms, fermentation and nutrient digestibility in swamp buffalo. Livestock Science 140(1): 17-23.

Cieslak A, Zmora P, Stochmal A, Pecio L, Oleszek W, Pers-Kamczyc E and Szumacher-Strabel M. 2014. Rumen antimethanogenic effect of Saponaria officinalis L. phytochemicals in vitro. The Journal of Agricultural Science 152(06): 981-93.

Elmnan B A, Jame N M, Rahmatalla S A, Amasiab E O and Mahala A G. 2013. Effect of fenugreek (Trigonella foenum- graecum) seeds supplementaion on feed intake, some metabolic hormones profile, milk yield and composition of Nubian goats. Research Journal of Animal Sciences 7(1): 1-5.

Firkins J L, Yu Z and Morrison M. 2007. Ruminal nitrogen metabolism: perspectives for integration of microbiology and nutrition for dairy. Journal of Dairy Science 90: E116.

Galindo J, González N, Abdalla A L, Alberto M, Lucas R C, Dos Santos K C and Sarduy L. 2016. Effect of a raw saponin extract on ruminal microbial population and in vitro methane production with star grass (Cynodon nlemfuensis) substrate. Cuban Journal of Agricultural Science 50(1): 5-10.

Giesy R G, Harris B, Giesy J G and Van Horn H H. 1992. Effectiveness of DeOdorase in reducing ammonia levels in dairy barns during summer months. In: Lyons T P (Ed.) Biotechnology in the Feed Industry. Proc. Alltech's 8th Annu. Symp. p 16. Alltech Technical Publications, Nicholasville, KY

Goel $G$ and Makkar H P. 2012. Methane mitigation from ruminants using tannins and saponins. Tropical Animal Health and Production 44(4): 729-39.

Goel G, Makkar H P and Becker K. 2008a. Effects of Sesbania sesban and Carduus pycnocephalus leaves and Fenugreek (Trigonella foenum-graecum L.) seeds and their extracts on partitioning of nutrients from roughage-and concentratebased feeds to methane. Animal Feed Science and Technology 147(1): 72-89.

Grobner M A, Johnson D E, Goodall S R and Benz D A. 1982. Sarsaponin effects on in vitro fermentation of a high grain diet. In: Proceedings of the Annual Meeting of the American Society of Animal Science, Western Section 33: 64- 65. Las Cruces, NM: Department of Animal and Range Science.

Guo Y Q, Liu J X, Lu Y, Zhu W Y, Denman S E and McSweeney C S. 2008. Effect of tea saponin on methanogenesis, microbial community structure and expression of morA gene, in cultures of rumen micro- organisms. Letters in Applied Microbiology 47(5): 421-26. 
Hassan S M, Haq A U, Byrd J A, Berhow M A, Cartwright A L and Bailey C A. 2010. Haemolytic and antimicrobial activities of saponin-rich extracts from guar meal. Food Chemistry 119(2): 600-05

Hess H D, Beuret R A, Lötscher M, Hindrichsen I K, Machmüller A, Carulla J E and Kreuzer M. 2004. Ruminal fermentation, methanogenesis and nitrogen utilization of sheep receiving tropical grass hayconcentrate diets offered with Sapindus saponaria fruits and Cratylia argentea foliage. Animal Science 79(1): 177-89

Hess H D, Kreuzer M, Diaz T E, Lascano C E, Carulla J E, Soliva C R and Machmüller A. 2003. Saponin rich tropical fruits affect fermentation and methanogenesis in faunated and defaunated rumen fluid. Animal Feed Science and Technology 109(1): 79-94.

Hess H D, Monsalve L M, Lascano C E, Carulla J E, Diaz T E and Kreuzer M. 2003. Supplementation of a tropical grass diet with forage legumes and Sapindus saponaria fruits: effects on in vitro ruminal nitrogen turnover and methanogenesis. Crop and Pasture Science 54(7): 703-13.

Hill, J., McSweeney, C., Wright, A.D., BishopHurley, G. and Kalantar-Zadeh, K. 2016. Measuring Methane Production from Ruminants. Trends of Biotechnology. 34:26-35

Holtshausen L, Chaves A V, Beauchemin K A, McGinn S M, McAllister T A, Odongo N E and and Benchaar C. 2009. Feeding saponin-containing Yucca schidigera and Quillaja saponaria to decrease enteric methane production in dairy cows. Journal of Dairy Science 92(6): 2809-21.

Hristov A N, McAllister T A, Van Herk F H, Cheng K J, Newbold C J and Cheeke P R. 1999. Effect of Yucca schidigera on ruminal fermentation and nutrient digestion in heifers. Journal of Animal Science 77(9): 2554-63.

Hussain I and Cheeke P R. 1995. Effect of dietary Yucca schidigera extract on rumen and blood profiles of steers fed concentrate-or roughage-based diets. Animal Feed Science and Technology 51(3-4): 231-42

$\mathrm{Hu}$ W, Liu J, Wu Y, Guo Y and Ye J. 2006.
Effects of tea saponins on in vitro ruminal fermentation and growth performance in growing Boer goat. Archives of Animal Nutrition 60(1): 89-97.

Hu W L, Liu J X, Ye J A, Wu Y M and Guo Y Q. 2005. Effect of tea saponin on rumen fermentation in vitro. Animal Feed Science and Technology 120(3): 333-39

Ismail A. 2000. Effect of fenugreek seeds (Trigonella foenum-groecum L.) as feed additive on sheep performance in the North Western coast of Egypt. In: Proceedings of 3rd All Africa Conf. Anim. Agric. 811th Conf, Egyptian Soc. Anim. Prod. Alexandria, Egypt, pp. 6-9

Istiqomah L, Hardian H, Febrisantosa A and Putra D. 2011. Waru leaf (Hibiscus tiliaceus) as saponin source on In vitro ruminal fermentation characteristic. Journal of the Indonesian Tropical Animal Agriculture 36(1): 43-49.

Jadhav R V. 2014. 'Studies on effect of supplementation of tea seed saponin on growth performance and nutrient utilization in goats'. M.V.Sc. Thesis, IVRI, Izatnagar, India.

Jouany J P. 1996. Effect of rumen protozoa on nitrogen utilization by ruminants. Journal of Nutrition 126(4): 1335S-46S.

Jouany J P and Morgavi D P. 2007. Use of 'natural' products as alternatives to antibiotic feed additives in ruminant production. Animal 1(10): 1443-46.

Kang J, Zeng B, Tang S, Wang M, Han X, Zhou C and Tan Z. 2016. Effects of momordica charantia saponins on in vitro ruminal fermentation and microbial population. Asian-Australasian Journal of Animal Sciences 29(4): 500.

Kawai M, Sato T, Kimura A, Takahashi J and Matsuoka S. 2000. Effect of Yucca schidigera on nitrogen and energy balance in sheep fed alfalfa or grass silage. Asian Australasian Journal of Animal Sciences 13: 218.

Klita P T, Mathison G W, Fenton T W and Hardin R T. 1996. Effects of alfalfa root saponins on digestive function in sheep. Journal of Animal Science 74(5): 1144-56.

Kumar M, Kannan A, Bhar R, Gulati A, Gaurav A and Sharma V K. 2017. Nutrient intake, 
digestibility and performance of Gaddi kids supplemented with tea seed or tea seed saponin extract. Asian-Australasian Journal of Animal Sciences 30(4): 486.

Li W and Powers W. 2015. Effects of saponin extracts on air emission from steers. Journal of Animal Science 90: 4001-13.

Lila Z A, Mohammed N, Kanda S, Kamada T and Itabashi H. 2003. Effect of sarsaponin on ruminal fermentation with particular reference to methane production in vitro. Journal of Dairy Science 86(10): 3330-36.

Lila Z A, Mohammed N, Kanda S, Kurihara M and Itabashi H. 2005. Sarsaponin effects on ruminal fermentation and microbes, methane production, digestibility and blood metabolites in steers. Asian Australasian Journal of Animal Sciences 18(12): 1746

Lovett D K, Stack L, Lovell S, Callan J, Flynn B, Hawkins M and O'Mara F P. 2006. Effect of feeding Yucca schidigera extract on performance of lactating dairy cows and ruminal fermentation parameters in steers. Livestock Science 102(1): 23-32.

Lu C D and Jorgensen N A. 1987. Alfalfa saponins affect site and extent of nutrient digestion in ruminants. Journal of Nutrition 117(5): 919-27.

Mader T L and Brumm M C. 1987. Effect of feeding sarsaponin in cattle and swine diets. Journal of Animal Science 65(1): 9-15

Makkar H P, Sen S, Blümmel M and Becker K. 1998. Effects of fractions containing saponins from Yucca schidigera, Quillaja saponaria, and Acacia auriculoformis on rumen fermentation. Journal of Agricultural and Food Chemistry 46(10): 4324-28.

Manatbay B, Cheng Y, Mao S and Zhu W. 2014. Effect of gynosaponin on rumen in vitro methanogenesis under different forageconcentrate ratios. Asian Australasian Journal of Animal Sciences (AJAS) 27(8): 1088-97.

Mao H L, Wang J K, Zhou Y Y and Liu J X. 2010. Effects of addition of tea saponins and soybean oil on methane production, fermentation and microbial population in the rumen of growing lambs. Livestock Science 129: 56-62.

Mirza I H, Khan A G, Azim A and Mirza M A. 2002. Effect of supplementing grazing cattle calves with urea-molasses blocks, with and without Yucca schidigera extract, on performance and carcass traits. Asian Australasian Journal of Animal Sciences 15(9): 1300-06.

Muetzel S. 2003. Supplementation of barley straw with Sesbania pachycarpa leaves in vitro: effects on fermentation variables and rumen microbial population structure quantified by ribosomal RNA-targeted probes. British Journal of Nutrition 89(04): 445-53.

Nasri S, Salem H B, Vasta V, Abidi S, Makkar H P S and Priolo A. 2011. Effect of increasing levels of Quillaja saponaria on digestion, growth and meat quality of Barbarine lamb. Animal Feed Science and Technology 164(1): 71-78.

Ningrat R W S, Garnsworthy P C and Newbold C J, 2002. Saponin fractions in Sapindus rarak: effects on rumen microbes. Reproduction Nutrition Development 42(1): 82.

Patra A K. 2012. Enteric methane mitigation technologies for ruminant livestock: a synthesis of current research and future directions. Environment Monitoring Assessment 184: 1929-52.

Patra A K, Kamra D N and Agarwal N. 2006. Effect of plant extracts on in vitro methanogenesis, enzyme activities and fermentation of feed in rumen liquor of buffalo. Animal Feed Science and Technology 128(3): 276-91.

Patra A K and Saxena J. 2009. Dietary phytochemicals as rumen modifiers: a review of the effects on microbial populations. Antonie van Leeuwenhoek 96(4): 363- 75.

Patra A K and Saxena J. 2010. A new perspective on the use of plant secondary metabolites to inhibit methanogenesis in ruminants. Phytochemistry 71: 1198- 22.

Patra A K, Stiverson J and Yu Z. 2012. Effects of quillaja and yucca saponins on communities and select populations of rumen bacteria and archaea, and fermentation in vitro. Journal of Applied Microbiology 113(6): $1329-40$

Patra A K and Yu Z. 2014. Effects of vanillin, quillaja saponin, and essential oils on in vitro fermentation and protein-degrading 
microorganisms of the rumen. Applied Microbiology and Biotechnology 98(2): 897-905.

Pen B, Sar C, Mwenya B, Kuwaki K, Morikawa R and Takahashi J. 2006. Effects of Yucca schidigera and Quillaja saponaria extracts on in vitro ruminal fermentation and methane emission. Animal Feed Science and Technology 129(3): 175-86

Pen B, Sar C, Mwenya B and Takahashi J. 2008. Effects of Quillaja saponaria extract alone or in combination with Yucca schidigera extract on ruminal fermentation and methanogenesis in vitro. Animal Science Journal 79: 193-99.

Petit P, Sauvaire Y, Ponsin G, Manteghetti M, Fave A and Ribes G. 1993. Effects of a fenugreek seed extract on feeding behaviour in the rat: Metabolic endocrine correlates. Pharmacology Biochemistry and Behavior 45: 369-74.

Ramírez-Restrepo C A, Tan C, O'Neill C J, López-Villalobos N, Padmanabha J, Wang J and McSweeney C S. 2016. Methane production, fermentation characteristics, and microbial profiles in the rumen of tropical cattle fed tea seed saponin supplementation. Animal Feed Science and Technology 216: 58- 67.

Rodríguez R and Fondevila M. 2012. Effect of saponins from Enterolobium cyclocarpum on in vitro microbial fermentation of the tropical grass Pennisetum purpureum. Journal of Animal Physiology and Animal Nutrition 96(5): 762-69

Russell, J.B. and Wallace, R. J. 1997. Energyyielding and energy-consuming reactions. In. The Rumen Microbial Ecosystem, Hobson PN, Stewart CS, editors. 2nd ed. London: Blackie Academic and Professional. pp. 246-82.

Santoso B, Kilmaskossu A and Sambodo P. 2007. Effects of saponin from Biophytum petersianum Klotzsch on ruminal fermentation, microbial protein synthesis and nitrogen utilization in goats. Animal Feed Science and Technology 137(1): 5868.

Santoso B, Mwenya B, Sar C, Gamo Y, Kobayashi T, Morikawa R and Takahashi J. 2004. Effect of Yucca schidigera with or without nisin on ruminal fermentation and microbial protein synthesis in sheep fed silage- and hay- based diets. Animal Science Journal 75(6): 525-31.

Sirohi S K, Goel N and Singh N. 2014. Influence of Albizia lebbeck saponin and its fractions on in vitro gas production kinetics, rumen methanogenesis, and rumen fermentation characteristics. ISRN Veterinary Science 2014: 1-9.

Śliwiński B J, Kreuzer M, Wettstein H R and Machmüller A. 2002.Rumen fermentation and nitrogen balance of lambs fed diets containing plant extracts rich in tannins and saponins, and associated emissions of nitrogen and methane. Archives of Animal Nutrition 56(6): 379-92.

Szczechowiak J, Szumacher-Strabel M, Stochmal A, Nadolna M, Pers-Kamczyc E, Nowak A and Cieślak A. 2013. Effect of Saponaria officinalis L. Or Panax ginseng CA Meyer Triterpenoid Saponins on Ruminal Fermentation in Vitro/Wpływ Saponin Triterpenowych Saponaria Officinalis L. Lub Panax Ginseng CA Meyer $\mathrm{Na}$ Przemiany Zachodzące W Żwaczu W Warunkach In Vitro. Annals of Animal Science 13(4): 815-27.

Szumacher-Strabel M and Cieslak A. 2010. Potential of phytofactors to mitigate rumen ammonia and methane production. Journal of Animal Feed Science 9: 319-37.

Thalib A, Widiawati Y, Hamid H, Suherman D and Sabrani M. 1995. The effects of saponins from Sapindus rarak fruit on rumen microbes and host animal growth. In: Annales de Zootechnie (Vol. 44, No. 1, pp. 161-161). Paris: Institut national de la recherche agronomique, 1960-2000.

Thalib A, Widiawati Y, Hamid H, Suherman D and Sabrani M. 1996. The effects of saponin from Sapindus rarak fruit on rumen microbes and performance of sheep. Indonesian Journal of Animal and Veterinary Sciences 2(1): 17-21.

Tomar K S, Singh V P, Yadav R S. 1996. Effect of feeding maithy (Trigonella foenumgraecum) and chandrasoor (Lepidium sativum L.) seeds on milk and blood constituents of Murrah buffaloes. Indian Journal of Animal Science 66(11): 1192-93. 
Wadhwa M and Bakshi M P S. 2009. Animal agriculture and green house gas emission: mitigation strategies. In: Pattanaik A K, Verma A K, Kamra D N and Sahrma K (Eds.) Proceedings Animal Nutrition Association World Conference on Animal Nutrition - preparedness to combat challenges, New Delhi, India Vol. I, pp. 119-22.

Wallace R J, Arthaud L and Newbold C J. 1994. Influence of Yucca shidigera extract on ruminal ammonia concentrations and ruminal microorganisms. Applied and Environmental Microbiology 60(6): 176267.

Wallace R J, McEwan N R, McIntosh F M, Teferedegne B and Newbold C J. 2002. Natural products as manipulators of rumen fermentation. Asian Australasian Journal of Animal Sciences 15(10): 1458-68.

Wang Y, McAllister T A, Newbold C J, Rode L M, Cheeke P R and Cheng K J. 1998. Effects of Yucca schidigera extract on fermentation and degradation of steroidal saponins in the rumen simulation technique (RUSITEC). Animal Feed Science and Technology 74(2): 143-53.

Wang Y, McAllister T A, Yanke L J and Cheeke P R. 2000. Effect of steroidal saponin from Yucca schidigera extract on ruminal microbes. Journal of Applied Microbiology 88(5): 887-96. fermentation and on production of lactating dairy cows. Journal of Dairy Science 69(6): 1568-75.

Wang J K, Ye J A and Liu J X. 2012. Effects of tea saponins on rumen microbiota, rumen fermentation, methane production and growth performance-A review. Tropical Animal Health and Production 44(4): 697706.

Wei-lian H, Yue-ming W U, Jian-xin L, Yan-qiu
G U O and Jun-an Y E. 2005. Tea saponins affect in vitro fermentation and methanogenesis in faunated and defaunated rumen fluid. Journal of Zhejiang University-Science B 6(8): 787- 92.

Wina E, Muetzel S, Hoffmann E, Makkar H P S and Becker K. 2005 Saponins containing methanol extract of Sapindus rarak affect microbial fermentation, microbial activity and microbial community structure in vitro. Animal Feed Science and Technology 121(1): 159-74.

Wu Z, Sadik M, Sleiman F T, Simas J M, Pessarakli M and Huber J T. 1994. Influence of yucca extract on ruminal metabolism in cows. Journal of Animal Science 72(4): 1038-42

Valdez F R, Bush L J, Goetsch A L and Owens F N. 1986. Effect of steroidal sapogenins on ruminal fermentation and on production of lactating dairy cows. Journal of Dairy Science 69(6): 1568-75.

Vincken J P, Heng L, de Groot A and Gruppen H. 2007. Saponins, classification and occurrence in the plant kingdom. Phytochemistry 68(3): 275-97.

Yurtseven, S., Cetin, M., Ozturk, I., Can, A., Boga, M., Sahin, T., and Turkoglu, H. (2009). Effect of different feeding method on methane and carbon dioxide emissions, milk yield and composition of lactating Awassi sheep. Asian J. Anim. Vet. $A d v, 4(6), 278-287$.

Yurtseven, S., and Ozturk, I. (2009). Influence of two sources of cereals (corn or barley), in free choice feeding on diet selection, milk production indices and gaseous products (CH4 and $\mathrm{CO} 2)$ in lactating sheep. Asian Journal of Animal and Veterinary Advances, 4(2), 76-85.

\section{How to cite this article:}

Anant Simran Singh and Prabhjot Kaur. 2020. Effect of Saponins Mitigation of Methane - A Review. Int.J.Curr.Microbiol.App.Sci. 9(06): 3310-3324. doi: https://doi.org/10.20546/ijcmas.2020.906.394 